\title{
Using geochemical investigations for determining the interaction between groundwater and saline water in arid areas: case of the Wadi Ouazzi basin (Morocco)
}

\author{
R. EL MOUKHAYAR ${ }^{1}$, M. BAHIR ${ }^{1}$, N. YOUBI ${ }^{1,2}$, N. CHKIR ${ }^{3}$, H. CHAMCHATI $^{1}$ \& \\ P. CARÉRA ${ }^{4}$ \\ 1 Cadi Ayyad University, Faculty of Science Semlalia, Department of Geology, 3GEO-LAB, Bd Prince My Abdellah, \\ PO Box2390, Marrakech, Morocco \\ rachid.elmoukhayar@edu.uca.ma \\ 2 Centro de Geologia da Universidade de Lisboa (CeGUL), Faculdade de Ciências (FCUL), Lisboa, Portugal \\ 3 Département de Géographie Faculté des Lettres et Sciences Humaines de Sfax, Tunisia \\ 4 Institut Technologuique et Nucléaire de Lisbonne, Portugal
}

The characteristics of the Essaouira basin water resources are a semi-arid climate, which is severely impacted by the climate (quantity and quality). Considering the importance of the Essaouira aquifer in the groundwater supply of the region, a study was conducted in order to understand groundwater evolution in this aquifer. The Essaouira aquifer is a coastal aquifer located on the Atlantic coastline of southern Morocco, corresponding to a sedimentary basin with an area of nearly $200 \mathrm{~km}^{2}$.

The control of the fluid exchange and the influence of mixing zones between the groundwater and saline water was investigated by sampling from 20 wells, drillings and sources belonging to the PlioQuaternary and Turonian aquifers.

It is hypothesized that groundwater major ions chemistry can be employed to determine the interaction between the groundwater and saline water (coastal aquifers). Groundwater samples examined for electric conductivity and temperature showed that waters belonging to the PlioQuaternary and Turonian aquifers present very variable electric conductivities, from $900 \mu \mathrm{s} / \mathrm{cm}$ to $3880 \mu \mathrm{s} / \mathrm{cm}$. Despite this variability, they are from the same family and are characterized by sodiumchloride facies. However, a good correlation exists between the electrical conductivity and chloride and sodium contents. The lower electrical conductivities are situated in the North quarter immediately to the south of the Wadi Ouazzi.

\section{PROJECT RELEVANT REFERENCES}

Bahir, M., et al. (2000) Contribution à l'étude des ressources hydriques du bassin synclinal d'Essaouira (Maroc). Estudios Geol. 56, $185-195$.

Bahir, M., Jalal, M. and Mennani, A. (2001) Pollution nitratée des eaux souterraines du bassin synclinal d'Essaouira.(Groundwater pollution by nitrates of the Essaouira synclinal basin). J. Environ. Hydrol. paper 18, vol. 9.

Bahir, M., et al. (1999). Contribution à l'étude hydrogéologique et hydrochimique de la zone synclinale d'Essaouira (Contribution to the study of the hydrogeology ande hydrochemistry of the Essaouira synclinal area). Congrès Intern. sur l'eau et la désertification. Le Caire.

Bertotti, G. and Gouiza, M. (2012) Post-rift vertical movements and horizontal deformations in the eastern margin of the Central Atlantic: Middle Jurassic to Early Cretaceous evolution of Morocco. Int. J. Earth Sci. 101, 2151-2165. Doi:10.1007/s00531-012-0773-4.

Chamchati, H. and Bahir, M. (2011) Contributions of climate change on water resources in semi-arid areas; example of the Essaouira Basin (Morocco). Am. J. Sci. Ind. Res. 2(2), 209-215.

Chamchati, H. and Bahir, M. (2011) Caractérisation du système aquifère plio-quaternaire et turonien (Bassin d'Essaouira, Maroc). Geohydro2011.

Chamchati, H., Bahir, M. and El Moukhayar, R. (2012) Groundwater chemical evolution in the Essaouira aquifer basin - NW Morocco. Am. J. Sci. Ind. Res. 2(1), 200-218.

Chamchati, H., Bahir, M. and El Moukhayar, R. (2012) Interactions groundwater-surface water and potential hydrogeological in Essaouira basin (Morocco ATLANTIC). Int. J. Hydrology Science and Technology 2(1).

Chamchati, H. et al. (2012) Vulnérabilité de la ressource en eau et défis du développement durable du Bassin d'Essaouira. Publication en série de livres de l'UNESCO: Intégrée des ressources en eau et les défis du développement durable.

Chkir, N. et al. (2008) Vulnérabilité des ressources en eau des aquifères côtiéres en zones semi-arides-etude comparative entre les bassin d'Essaouira (Maroc) et la Jeffara (Tunisie). Comunicaçoes Geologicas 95, 107-121.

Döll, P. (2002) Impact of climate change and variability on irrigation requirements: a global perspective. Climatic Change 54, $269-293$.

Duffaud, F., Brun, L. and Planchot, B. (1966) Bassin du sud-ouest marocain (SW Morocco basin). In: Reyre (ed.) Bassin sédimentaire du littoral africain. Ass. Serv. Géol. Africain. 1ère partie, Paris, 5-12. 
Ettachfini, E. M. (1992) Le Vraconien, Cénomanien et Turonien du bassin d'Essaouira (Haut Atlas ocidental,Maroc): Analyse lithologique, biostratigraphique et sédimentologique, stratigraphie séquentielle. Thèse Univ.Paul Sabatier-Toulouse, $245 \mathrm{pp}$

Fekri, A. (1993) Contribution à l'étude hydrogéologique et hydrogéochimique de la zone synclinale d'Essaouira (Bassin synclinal d'Essaouira). 3rd cycle dissert.

Galego Fernandes, P., et al. (2005) Anthropogenic feactures in the Sines (Portugal) ans Essaouira (Maroc) coasltal aquiferes: a comparative study of their hydrochemical evolution by a principal component analysis. Estudios Géol. 61, 207-219. 